\title{
KNOWLEDGE-INTENSIVE SPECIALISATION AND TOTAL FACTOR PRODUCTIVITY (TFP) IN THE EU REGIONAL SCOPE
}

\author{
Tomasz Kijek ${ }^{1}$, Anna Matras-Bolibok ${ }^{1}$ \\ ${ }^{1}$ Department of Microeconomics and Applied Economics, Institute of Economics and Finance, Faculty of \\ Economics, Maria Curie-Sklodowska University, Plac Marii Curie-Skłodowskiej 5, 20-031 Lublin, Poland
}

Link to this article: https://doi.org/10.11118/actaun202068010181

Received: 3. 6. 2019, Accepted: 6. 12. 2019

To cite this article: KIJEK TOMASZ, MATRAS-BOLIBOK ANNA. 2020. Knowledge-intensive Specialisation and Total Factor Productivity (TFP) in the EU Regional Scope. Acta Universitatis Agriculturae et Silviculturae Mendelianae Brunensis, 68(1): 181-188.

\begin{abstract}
The aim of the paper is to assess the impact of knowledge-intensive specialisation on Total Factor Productivity (TFP) in the EU regional scope. To calculate TFP defined as the aggregated output-input ratio, we employ the multiplicatively-complete Färe-Primont index as it satisfies all economicallyrelevant axioms and tests from the index number theory. The knowledge intensive specialisation of EU regions is captured by the statistics on high-tech industry and knowledge-intensive services, i.e. the employment in high-tech sectors as a percentage of total employment (HTS). The research sample consists of $248 \mathrm{EU}$ regions at NUTS 2 level. The key findings of the study indicate that the employment in high-tech manufacturing and knowledge-intensive services is not distributed uniformly in the EU regional space. Similarly, TFP also varies substantially across the EU regions. Moreover, the results of the research model estimation show that specialisation in high-tech manufacturing and knowledge-intensive services directly affects regional TFP. The main implication of our analysis for the policymakers is to explore and support knowledge-intensive specialisation patterns, that should be built upon existing regional technological competencies and human capital endowment according to the smart specialisation strategies approach.
\end{abstract}

Keywords: regional specialisation, knowledge-intensive specialisation, TFP, productivity, innovation, regional policy, Färe-Primont index, EU regions

\section{INTRODUCTION}

Differences in the level of economic development within the EU countries are large and persistent (Iammarino et al., 2017). An evidence in the relevant literature supports the view that the existing disparities in regional economic development can be predominantly attributed to the differences in total factor productivity (TFP) (Easterly and Levine, 2001; Beugelsdijk et al., 2018). Therefore, the question arises which factors contribute to the differences in the level of productivity in the EU regional space.

So far, the studies in the relevant literature investigated the impact of intangible factors (human capital, social capital and technological capital) on the TFP levels in the EU regions (Dettori et al., 2012) or examined the relative importance of the drivers of TFP in the manufacturing sector of EU countries, namely Foreign Direct Investment (FDI), investment in Information and Communication Technologies (ICT), human capital, R\&D, trade openness and rationalization efforts (Gehringer et al., 2014). Moreover, the empirical evidence indicated that TFP disparities could reflect different structures of regional economies (International Monetary Fund, 2018) and that the productivity dynamics is differentiated by the effects of agglomeration 
externalities (Marrocu et al., 2013). It was also demonstrated that changes in specialisation have direct consequences on regional productivity rates, which in turn may result in regional economic development imbalances (Mora and Moreno, 2010).

Facing persistent differences in the level of innovativeness and productivity across European regions, the EU policy has recently shifted toward the so-called smart specialisation approach that became its dominant paradigm (European Commission, 2010). In this light the analysis of the relationship between specialisation, in particular in knowledge and innovation-driven sectors, and TFP seems to be an interesting research problem. The direct empirical evidence on the relationship between knowledge intensive specialisation and TFP on the regional level is however limited.

Bearing in mind the above considerations, and in order to address the identified gap in the relevant literature the aim of the paper is to assess the impact of knowledge-intensive specialisation on TFP levels in the EU regions.

The value added of this paper lies mostly in the following three aspects. Firstly, the paper contributes to research on the impact of knowledge intensive specialization on productivity at the regional level. The studies so far have analysed and assessed this issue at the country level. The existence of large disparities among European regions provides a sufficient justification for choosing the regional (NUTS 2) scope of the analysis instead of national level. It is worth to point out that large differences among regions in Europe have important implications for designing economic policies of EU. Secondly, our paper examines the impact of regional specialisation on TFP, whereas the evidence in the relevant literature, so far, focuses on the impact of specialisation on labour productivity growth (Piras et al., 2012) or economic growth (GDP per capita) (Evangelista et al., 2015). Lastly, our results demonstrates the TFP spillovers within European regions, but these processes are not explicitly realized by the employees from the high-tech sectors. The results of our analysis have important policy implications as they indicate the significance of knowledge intensive specialization in European regions in shaping their productivity growth and designing their smart specialization strategies.

In order to shed light on the formulated research problem we analyse the spatial distribution of knowledge intensive specialization across EU regions, captured by the statistics on employment in high-tech manufacturing and knowledge-intensive services. Similarly, we examine the distribution of TFP levels in the EU regional space. To calculate TFP we employ the multiplicatively-complete Färe-Primont index. To assess the impact of knowledge intensive specialisation on TFP we use the linear regression with both endogenous and exogenous spatial lags. The research sample covers 248 European regions at the NUTS 2 level, over the 2014-2016 period.
The remainder of the paper is organised as follows. The next section presents the literature review on the role of knowledge intensive specialization in shaping the regional productiveness. The third section describes the data sources and methods employed to assess the spatial distribution of knowledgeintensive specialisation and TFP and the relationship between them in the EU regions. The fourth section demonstrates the results of the analysis along with discussion of the key findings. Finally, the last section recapitulates the main conclusions of the study, presents policy implications, and provides some suggestions for further research.

\section{Literature Review}

The assorted literature on specialisation is rooted in Marshall's theory (1920). Most recently, specialisation is not understood as concentration within one sector, but it is actually defined as "related variety", as according to Grillitsch et al. (2018) competitive advantage depends on local knowledge resources but also on linkages between related entities, which accelerate learning and innovation processes. This viewpoint emphasizing that related economic activities should be considered as regional specialisation is presented also by Kemeny and Storper (2015). Also Frenken et al. (2007) argue that distinctive, but simultaneously related, regional industrial structure has a positive impact on a longrun innovativeness, as closely related activities create basis for interaction, leading to innovation and productivity growth.

Benefits from specialisation are essential to knowledge-intensive and innovation activities. The empirical evidence provided by Foray (2014) indicates that there are substantial indivisibilities in knowledge production and the proximity of a sufficiently large R\&D sector is needed. Additionally, his research also revealed that the existence of economies of scale, economies of scope and spillovers is an essential determinant of the productivity of innovation activities.

According to the New Economic Geography (NEG) paradigm (Krugman, 1998), geographical concentration and localised spillovers are beneficial for productivity and growth (Ottaviano and Thisse, 2004). The productivity dynamics is differentiated by the effects of agglomeration externalities according to the product life cycle and the maturity stage of a given area (Marrocu et al., 2013). As Kemeney and Storper (2015) point out, regional specialisation should positively impact productivity through the three main mechanisms assumptive in the NEG models: sharing of input suppliers, matching of specialized labour demand and supply, and occurrence of technological learning or spillovers effects, especially where innovation involves many different types of actors spread across different organizations. 
Midelfart-Knarvik et al. (2000) indicate several determinants of regional specialisation, including in particular: human capital and the existence of a specialised regional labour pool, the presence of agglomeration economies, regional investments and innovation activities. Localisation and urbanisation externalities favour regional specialisation as economic activities tend to cluster in dense urban areas with a strong functional specialisation in knowledge-intensive and high-skilled activities (Meliciani and Savona, 2015). Regional specialisation may be also affected by the specialisation behaviour of other regions (Mora and Moreno, 2010). Spillovers within the same industry are thought to be more substantial than those across industries. Peer regions, similarly specialised in low or hightech sectors, are expected to have the highest impact on regional specialisation changes. What is worth to point out however, Mora and Moreno (2010) also demonstrate that physical distance plays still significant, and even more influential, role than similarity in specialisation.

According to Jungmittag (2014) two kinds of specialisation can be distinguished, on the basis of the new growth theory: Smithian and Ricardian specialisation. The first one leads to the occurrence of learning-by-doing effects and increasing returns to scale, independent of the technological areas in which a given economy is specialised. The second one, stresses the qualitative character of an economy's technological specialisation, considered as an opportunity for higher productivity growth. This viewpoint could be observed in R\&D growth models (Romer, 1990; Grossmann and Helpman, 1991).

The tendency observed both on regional and national level that the factors of production are accumulated in spatial proximity, implies that innovation activity is highly concentrated (Jung and López-Bazo, 2017). Accumulation of factors results in positive externalities and, as a consequence, only certain places achieve higher productivity levels (Moreno et al., 2005). Such inequality in the levels of productivity, caused by the spatial dependence of productivity distribution along time is typical for $\mathrm{EU}$ as the changes in this factor have a significant geographical component (Di Liberto and Usai, 2013).

A crucial measure of productivity is Total Factor Productivity (TFP). TFP is the part of output which cannot be directly attributed to the amount of inputs used in the production process. The level of TFP thus determines how efficiently and intensely the available inputs are used in production. A survey provided by Del Gatto et al. (2010) reviews and classifies most of the available methodologies and approaches for productivity estimation according to three main criteria: macro vs. micro, frontier vs. nonfrontier, and deterministic vs. econometric. In the several studies investigating the differences in TFP performance across countries or regions frontier models are applied (eg. Enflo and Hjertstrand,
2006). Under this approach productivity growth is broken down into components attributable to efficiency change, technological progress and capital accumulation (Salinas-Jiménez, 2003). TFP is decomposed by means of productivity indexes, in particular the Malmquist index, which seems to be the most frequently employed in the empirical analyses. However, as O’Donnell (2012) argues, the Malmquist TFP index is incomplete as he points out that multiplicatively-complete aggregated TFP indexes are better applicable in wider economic contexts. One of them is the Färe-Primont index, which we employ in the analyses conducted in the present paper.

Empirical analyses confirm the presence of a high and persistent level of TFP heterogeneity across EU regions and regional productivity polarisation between high and low TFP levels (Di Liberto and Usai, 2013). Facing such differences in the level of innovativeness and productivity across European regions, the EU policy has recently shifted toward the so-called smart specialisation approach that became its dominant paradigm, constituting a key pillar for the Cohesion Policy of the European Commission for the period 2014-2020. According to Foray (2014) the concept of smart specialisation refers to "the capacity of an economic system (a region for example) to generate new specialities through the discovery of new domains of opportunity and the local concentration and agglomeration of resources and competences in these domains". The smart specialisation could be described as a framework for prioritizing the allocation of innovative resources that are pivotal to a given region. As each region shows a particular economic trajectory, it demands specific and place-based policies (González-López et al., 2019). Following the smart specialisation strategies approach should release positive knowledge externalities both within as well as between regions. In particular, these strategies are crucial for the regions characterized by low TFP levels (Mc Cann and Ortega-Argilés, 2015).

Considering the fact that knowledge intensive activities are significantly concentrated across the European regional space (Marrocu et al., 2013), we expect their significant impact on differences in TFP levels. This notion allows us to formulate the key hypothesis of the study:

H1: Knowledge-intensive specialisation has a significant positive impact on TFP.

\section{MATERIALS AND METHODS}

\section{Research Design}

Our empirical analysis uses data referring to a sample of 248 European regions at the NUTS 2 level, and taking into account the years 2014-2016. The NUTS 2 level (basic regions) is appropriate for complex economic analyses, since it is used by Member States to apply their regional policies. On 
the other hand, the NUTS 3 level may be applied for analyses, where more specific regional measures should be taken. The knowledge intensive specialisation of EU regions is captured by the statistics on high-tech industries and knowledgeintensive services, i.e. the employment in high-tech sectors as a percentage of total employment (HTS). The data provided by the Eurostat are aggregated according to the sectoral approach. In the case the manufacturing industries, the aggregation is based on technological intensity (i.e. R\&D expenditure/value added). In turn, services are aggregated into knowledge-intensive services on the basis of the share of tertiary educated persons at NACE 2-digit level. As such, high-tech industries include: the manufacture of basic pharmaceutical products and their preparations, the manufacture of computer, electronic and optical products, while high-tech knowledge-intensive services contain: motion picture, video and television programme production, sound recording and music publish activities, programming and broadcasting activities, telecommunications, computer programming, consultancy and related activities, information service activities, and scientific research and development.

For the purpose of TFP calculation, we employ two inputs one and output. Our measures of the input variables are employment (E) in thousand hours worked and gross fixed capital formation (GFCF), which consists of resident producers' investments, deducting disposals, in fixed assets during a given period. The output variable is gross domestic product (GDP) at current market prices. The regional data on GDP, employment and gross fixed capital formation have been derived from the Eurostat.

The Färe-Primont index is used to calculate the aggregated output-input ratio, i.e. the total factor productivity (TFP). Due to its properties (i.e. determinateness and transitivity), this index is better than other more popular productivity indices (e.g. the Malmquist index) (Briec et al., 2018). O'Donnell (2011) shows that this index fulfils all economically-relevant axioms and tests from index number theory. The class of linearly homogeneous, non-negative, and non-decreasing output-input aggregator functions applied in the Färe-Primont index are as follows (O’Donnell 2011):

$Q(q)=D_{0}\left(x_{0}, q, t_{0}\right)$
$X(x)=D_{1}\left(x, q_{0}, t_{0}\right)$,

where $x_{0}$ and $q_{0}$ are vectors of representative input and output quantities, $t_{0}$ denotes a representative time period, and $D_{0}\left(\right.$.) and $D_{1}($.$) are output and input$ distance functions.

As mentioned previously, there are several parametric and semiparametric estimators applied to TFP estimation, besides non-parametric methods (including the Färe-Primont index). Van Beveren (2010) provides an excellent review of the former group. As suggested by Van Biesebroeck (2007), the non-parametric methods should be preferred over the parametric and semiparametric ones, when technology is heterogeneous, returns to scale are not constant, and measurement error is relatively small.

In order to find the impact of HTS on TFP we use the linear regression with both endogenous and exogenous spatial lags, i.e. the spatial Durbin model (Elhorst 2010). The model is given as:

$y_{i t}=\rho \sum_{i \neq j} w_{i j} y_{j t}+x_{i t} \beta+\sum_{i \neq j} w_{i j} X_{j t} \theta+\mu_{i}+\varepsilon_{i t}$,

where: $w_{i j}$ - the spatial weighting matrix and $\mu_{i}$ - panel-level effects, which may be fixed or random.

The spatial weight matrix is calculated as the contiguity matrix for first-order neighbours. We use the raw normalization for this matrix. We fit the above model by applying the maximum likelihood method.

\section{RESULTS AND DISCUSSION}

Tab. I displays the summary statistics of our data. We see that the average level of TFP is 0.3, while the average employment in the sample regions is $3.65 \%$. It should be noted that the average level of TFP was slightly decreasing in the analysed period. On the other hand, the opposite trend was observed in the case of the employment in high-tech sectors.

Fig. 1 shows the average employment in hightech manufacturing and knowledge-intensive services at the regional level. High employment in high-tech sectors is frequently seen in capital regions or neighbouring regions to capitals. The Berkshire, Buckinghamshire and Oxfordshire region of the United Kingdom, which is located close to London, has $10.8 \%$ of its employed people in high-tech sectors. Similarly, one out of ten

I: Summary statistics

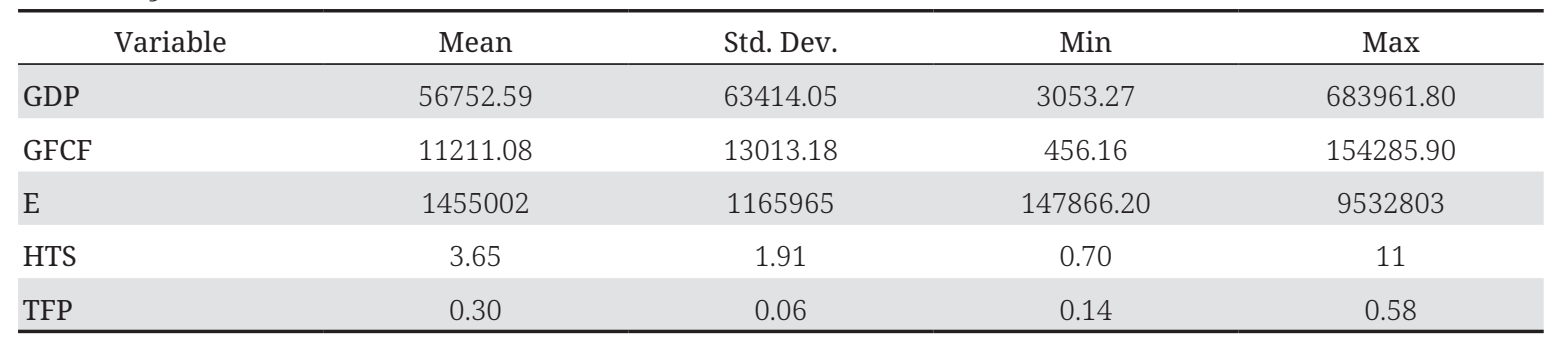


employees is employed in the high-tech sectors in Helsinki-Uusimaa region. Other examples include Hovedstaden (Denmark) with 9.5\%, Praha (Czechia) with 9.2\%, Inner London and Warszawski stołeczny (Poland) with 9.1\%, and Bratislavský kraj (Slovakia) with $8.9 \%$. On the contrary, the lowest ratio (below 1\%) were reported in Sud - Est (Romania), Anatoliki Makedonia, and Peloponissos (Greece).

At national level, Portugal, Slovakia, Romania, Finland, and Belgium show the largest regional variation of the average employment in high-tech sectors (i.e. the interquartile range), while the smallest variation is observed in Austria and Bulgaria (Fig. 2). Some important differences among countries also emerge when comparing the positional average (i.e. median) of HTS. For countries with more than one region, the highest national values were registered in
Slovakia, the United Kingdom, Czechia, and Belgium, while the lowest value was observed in Greece.

As regards the average level of TFP, the most productive regions in EU are placed along the United Kingdom, Germany and Italy corridor (Fig. 3 while the lowest levels of TFP are situated in peripheral regions of Eastern Europe (i.e. Bulgaria, Poland and Romania). What is worth noting, the extremely low TFP scores for these regions are also reported by Beugelsdijk, Klasing and Milionis (2018).

Tab. II shows the results of the spatial Durbin model estimation. Our model accounts for 57\% of the total variance of TFP. In order to take into account the institutional proximity among regions located in particular countries, we included country dummies in the model. A similar approach was used by Kijek and Kijek (2019) to study knowledge

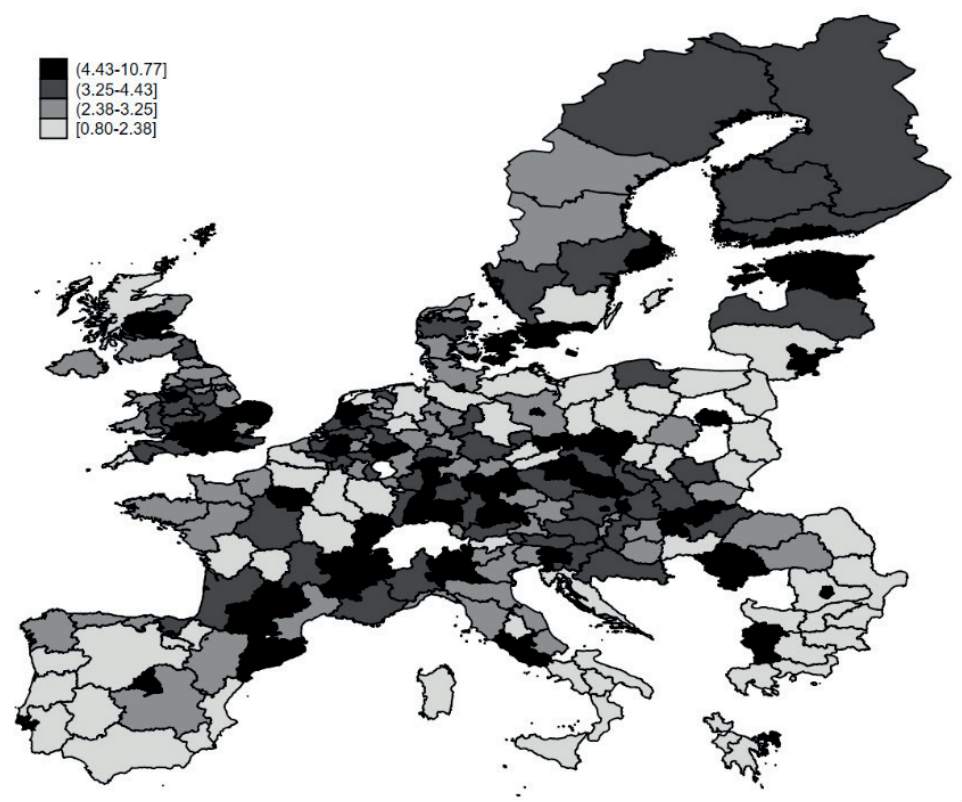

1: Employment in high-tech sectors in the EU regions [\%]

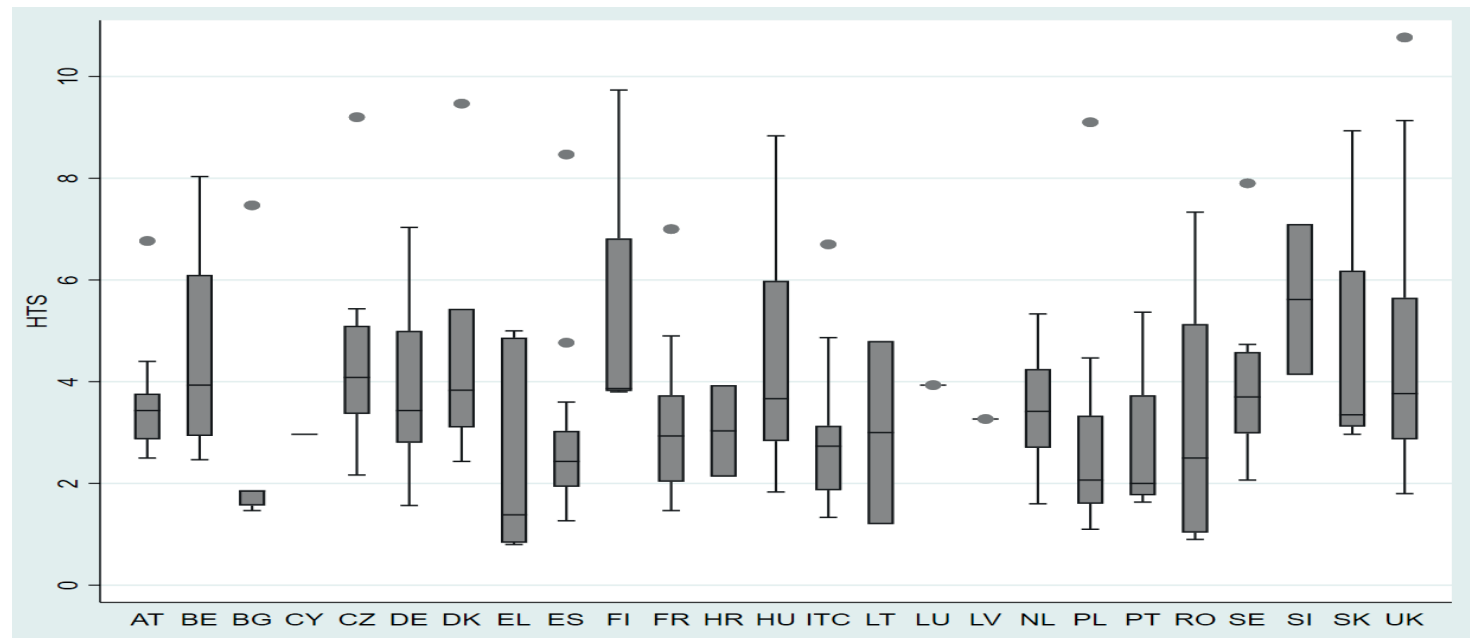

2: Regional disparities in employment in high-tech sectors 


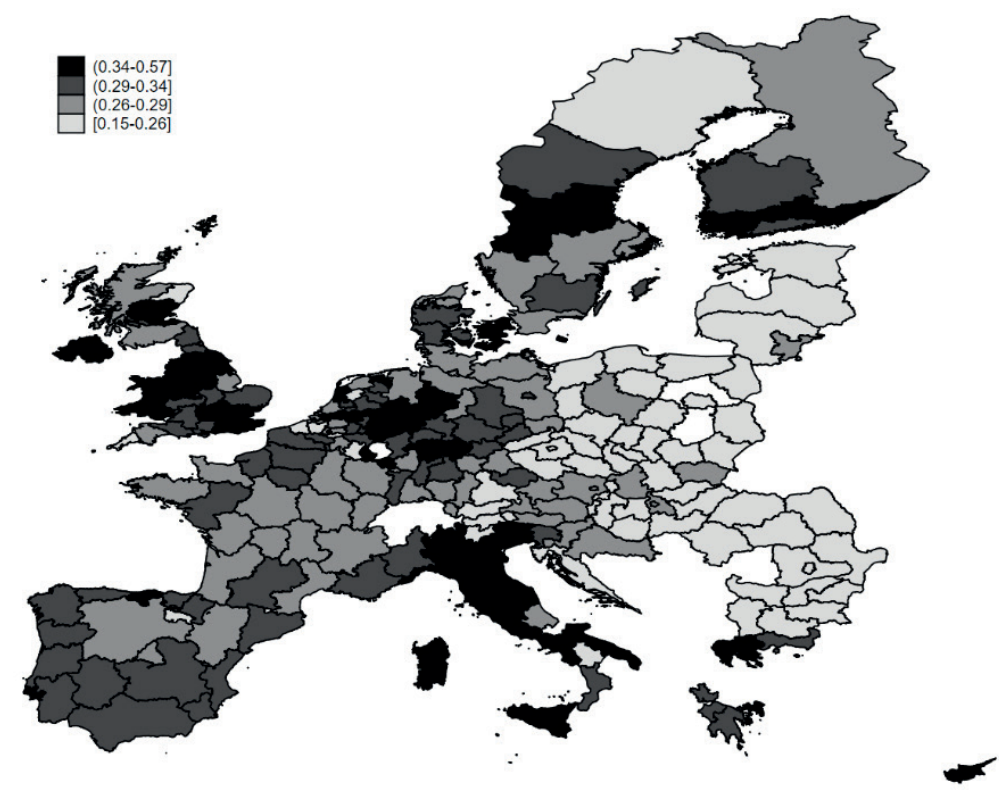

3: TFP in EU regions

II: Estimates of model parameters

\begin{tabular}{lllccc}
\hline & TFP & Coef. & Std. Err. & $\mathrm{z}$ & $\mathrm{P}>|\mathrm{z}|$ \\
\hline \multirow{2}{*}{ TFP } & HTS & 0.003 & 0.001 & 2.54 & 0.011 \\
\hline $\mathrm{W}$ & Cons. & 0.279 & 0.016 & 17.81 & 0.000 \\
\hline Country specific dummies & HTS & 0.002 & 0.002 & 0.83 & 0.409 \\
Direct effect & TFP & 0.150 & 0.039 & 3.81 & 0.000 \\
\hline Indirect effect & HTS & 0.003 & 0.001 & 2.62 & 0.009 \\
Total effect & HTS & 0.003 & 0.002 & 1.07 & 0.282 \\
\hline Wald test of spatial terms: chi2(2) $=19.08$; Prob > chi2 = 0.000; Pseudo R2 $=0.57$ & & 0.029 \\
\hline
\end{tabular}

spillovers within European regions. Analysing the direct effect of HTS on TFP, we notice that the increase of own employment in high-tech sectors results in higher regional TFP. This finding supports our hypothesis. As mentioned previously, hightech sectors are key drivers of economic growth and productivity, and finally provide high valueadded employment. Moreover, high-tech sectors play a key role in international trade and their development allows for improving performance in other sectors. For example, Evangelista et al. (2015) show that technological specialisation matters for the regional productivity growth. They argue that specialisation in key enabling technologies - KETs provides benefits for both technologically developed regions and technology backward regions. What is important, the effects of KETs are supposed to be stronger in the latter group.

Looking at the indirect effect of HTS, we find that it is insignificant. However, we should notice that the spatial autocorrelation parameter $\rho$ is relatively large and significant. This finding, in turn, suggests that TFP spills over from nearby regions, but its diffusion is not explicitly realized by the employees from the high-tech sectors. On the one hand, one would expect that the increase of employment in high-tech sectors in a region leads to the increase of its TFP and spurs additional (codified) knowledge flows into neighboring regions. On the other hand, the positive effects of human capital spillovers may be only found when the complementary stock of regional R\&D is accumulated (Kijek and Kijek 2019). 


\section{CONCLUSION}

The main results of this paper can be summarised as follows. First, TFP varies substantially across the EU regions. The extremely low TFP scores were observed in peripheral regions of Eastern Europe. Second, the employment in high-tech manufacturing and high-tech knowledge-intensive services is not distributed uniformly in the EU regional space. High employment in high-tech sectors was recorded in capital regions or neighbouring regions to capitals. Finally, the results of the research model estimation show that specialisation in high-tech manufacturing and high-tech knowledgeintensive services directly affects regional TFP.

The results of this study allow for drawing some policy implications. The main implication of our analysis for policymakers is to explore and support knowledge-intensive specialisation patterns. The patterns of specialisation should be built upon existing regional technological competencies and human capital endowment. According to the smart specialisation theory policymakers should develop learning networks and deepen the linkages within the region in the promising fields of specialisation (Foray et al., 2011). As suggested by Boschma et al. (2012), more diversified regions have better growth opportunities than strongly specialised regions.

Beyond the presented results, this study paves the way for different avenues of future research. For example, it might be interesting to identify whether specialisation in high tech manufacturing is a complimentary or substitute strategy to specialisation in knowledge-intensive services. Moreover, future research should focus on emerging technological areas and finding their impact on regional growth.

\section{Acknowledgements}

The project was financed by National Science Centre, Poland on the basis of decision number 2017/27/B/HS4/00893.

\section{REFERENCES}

BEUGELSDIJK, S., KLASING, M. J. and MILIONIS, P. 2018. Regional economic development in Europe: the role of total factor productivity. Regional Studies, 52(4): 461-476.

BOSCHMA, R.A., MINONDO, A. and NAVARRO, M. 2012. Related variety and regional growth in Spain. Papers in Regional Science, 91(2): 241-256.

BRIEC, W., KERSTENS, K., PRIOR, D. and VAN DE WOESTYNE, I. 2018. Testing general and special FärePrimont indices: A proposal for public and private sector synthetic indices of European regional expenditures and tourism. European Journal of Operational Research, 271: 756-768.

DEL GATTO, M., DI LIBERTO, A. and PETRAGLIA, C. 2011. Measuring Productivity. Journal of Economic Surveys, 25(5): 952-1008.

DETTORI, B., MARROCU, E. and PACI, R. 2012. Total factor productivity, intangible assets and spatial dependence in the European regions. Regional Studies, Taylor \& Francis Journals, 46(10): 1401-1416.

DI LIBERTO, A. and USAI, S. 2013. TFP Convergence Across European Regions: A Comparative Spatial Dynamics Analysis. In: CRESCENZI, R. and PERCOCO, M. (Eds.). Geography, Institutions and Regional Economic Performance. Advances in Spatial Science. The Regional Science Series. Berlin, Heidelberg: Springer.

ELHORST, J. P. 2010. Applied spatial econometrics: Raising the bar. Spatial Economic Analysis, 5(1): 9-28.

EUROPEAN COMMISSION. 2010. Europe 2020: A strategy for smart, sustainable and inclusive growth. $\operatorname{COM}(2010) 2020$ final. Brussels: EC.

EASTERLY, W. and LEVINE, R. 2001. It's Not Factor Accumulation: Stylized Facts and Growth Models. The World Bank Economic Review, 15(2): 177-219.

ENFLO, K. and HJERTSTRAND, P. 2006. Relative sources of European regional productivity convergence: A bootstrap frontier approach. Working Papers 2006:17. Lund University, Department of Economics.

EVANGELISTA, R., MELICIANI, V. and VEZZANI, A. 2015. The Specialisation of EU Regions in Fast Growing and Key Enabling Technologies. JRC Technical Report, EUR 27524 EN. European Commission.

FORAY, D. 2014. Smart Specialisation: Opportunities and Challenges for Regional Innovation Policy. New York: Routledge.

FORAY, D., DAVID, P. and HALL, B. H. 2011. Smart specialisation: from academic idea to political instrument, the surprising career of a concept and the difficulties involved in its implementation, MTEI Working Paper. École Polytechnique Fédérale de Lausanne.

FRENKEN, K., VAN OORT, F. G. and VERBURG, T. 2007. Related variety, unrelated variety and regional economic growth, Regional Studies, 41(5): 685-697. 
GEHRINGER, A., MARTÍNEZ-ZARZOSO, I. and NOWAK-LEHMANN DANZINGER, F. 2014. TFP estimation and productivity drivers in the European Union. CEGE Discussion Papers, No. 189. University of Göttingen, Center for European, Governance and Economic Development Research (CEGE).

GONZÁLEZ-LÓPEZ, M., ASHEIM, B. and DEL CARMEN SÁNCHEZ CARREIRA, M. 2019. New insights on regional innovation policies, Innovation. The European Journal of Social Science Research, 32(1): 1-7.

GRILLITSCH, M., ASHEIM, B. and TRIPPL, M. 2018. Unrelated knowledge combinations: the unexplored potential for regional industrial path development. Cambridge Journal of Regions, Economy and Society, 11: 257-274.

GROSSMAN, G. and HELPMAN, E. 1991. Innovation and Growth in a Global Economy. Cambridge: MIT Press.

IAMMARINO, S., RODRÍGUEZ-POSE, A. and STORPER, M. 2017. Why Regional Development matters for Europe's Economic Future. Working Papers 07/2017 of the Directorate-General for Regional and Urban Policy. Luxembourg: Publications Office of the European Union.

INTERNATIONAL MONETARY FUND. 2018. Spain. Selected Issues. IMF Country Report No. 18/331. Washington: IMF.

JUNG, J. and LÓPEZ-BAZO, E. 2017. Factor Accumulation, Externalities and Absorptive Capacity in Regional Growth: Evidence from Europe. Journal of Regional Science, 57(2): 266-289.

JUNGMITTAG, A. 2004. Innovations, technological specialisation and economic growth in the EU, International Economics and Economic Policy, 1: 247-273.

KEMENY, T. and STORPER, M. 2015. Is specialisation good for regional economic development? Regional Studies, 49: 100-1018.

KIJEK, A. and KIJEK, T. 2019. Knowledge Spillovers: An Evidence from The European Regions. Journal of Open Innovation: Technology, Market, and Complexity, 5(3): 68.

KRUGMAN, P. 1998. What's New about the New Economic Geography? Oxford Review of Economic Policy, 14(2): 7-17.

MARROCU, E., PACI R. and USAI, S. 2013. Productivity Growth in the Old and New Europe: the Role of Agglomeration Externalities. Journal of Regional Science, 53(3): 418-442.

MARSHALL, A. 1920. Principles of Economics: An Introductory Volume. London: Macmillan.

McCANN, P. and ORTEGA-ARGILÉS, R. 2015. Smart Specialisation, Regional Growth and Applications to European Union Cohesion Policy. Regional Studies, 49(8): 1291-1302.

MELICIANI V. and SAVONA, M. 2015. The determinants of regional specialisation in business services: agglomeration economies, vertical linkages and innovation. Journal of Economic Geography, 15(2): 387-416.

MIDELFART-KNARVIK, K., OVERMAN, H. and VENABLES, A. 2000. Comparative advantage and economic geography; estimating the determinants of industrial location in the EU. CEPR Discussion Paper No. 2618. CEPR.

MORA, T. and MORENO, R. 2010. Specialisation changes in European regions: the role played by externalities across regions. Journal of Geographical Systems, 12: 311-334.

MORENO, R., PACI, R., and USAI, S. 2005. Spatial Spillovers and Innovation Activity in European Regions. Environment and Planning A: Economy and Space, 37(10): 1793-1812.

O’DONNELL, C. J. 2011. DPIN 3.0. A program for decomposing productivity index numbers. Australia, Queensland: University of Queensland.

OTTAVIANO, G. and THISSE, J. F. 2004. Agglomeration and economic geography. In: HENDERSON, V. and THISSE, J. F. (Eds.). Handbook of Regional and Urban Economics. Volume 4, Cities and Geography. North Holland.

PIRAS, G., POSTIGLIONE, P. and AROCA, P. 2012. Specialization, R\&D and productivity growth: evidence from EU regions. The Annals of Regional Science, 49(1): 35-51.

ROMER, P. M. 1990. Endogenous technological change. Journal of Political Economy, 98: S71-S102.

SALINAS-JIMÉNEZ, M. 2003. Efficiency and TFP Growth in the Spanish Regions: The Role of Human and Public Capital. Growth and Change, 34(2): 157-174.

VAN BIESEBROECK, J. 2007. Robustness of productivity estimates. Journal of Industrial Economics, 55(3): 529-569.

VAN BEVEREN, I. 2012. Total factor productivity estimation: A practical review. Journal of economic surveys, 26(1): 98-128.

VON HIPPEL, E. 1994. "Sticky Information" and the Locus of Problem Solving: Implications for Innovation. Management Science, 40(4): 429-439.

Contact information

Tomasz Kijek: tomasz.kijek@poczta.umcs.lublin.pl

Anna Matras-Bolibok: anna.matras@poczta.umcs.lublin.pl 